University of Nebraska - Lincoln

DigitalCommons@University of Nebraska - Lincoln

\title{
Survival of the western pond turtle (Emys marmorata) in an urban California environment
}

\author{
Phillip Q. Spinks \\ University of California - Davis, pqspinks@ucdavis.edu \\ Gregory B. Pauly \\ University of California - Davis, gbpauly@mail.utexas.edu \\ John J. Crayon \\ USGS, jack_crayon@usgs.gov \\ H. Bradley Shaffer \\ University of California - Davis, hbshaffer@ucdavis.edu
}

Follow this and additional works at: https://digitalcommons.unl.edu/usgsstaffpub

Spinks, Phillip Q.; Pauly, Gregory B.; Crayon, John J.; and Shaffer, H. Bradley, "Survival of the western pond turtle (Emys marmorata) in an urban California environment" (2003). USGS Staff -- Published Research. 526.

https://digitalcommons.unl.edu/usgsstaffpub/526

This Article is brought to you for free and open access by the US Geological Survey at DigitalCommons@University of Nebraska - Lincoln. It has been accepted for inclusion in USGS Staff -- Published Research by an authorized administrator of DigitalCommons@University of Nebraska - Lincoln. 


\title{
Survival of the western pond turtle (Emys marmorata) in an urban California environment
}

\author{
Phillip Q. Spinkss, b,*, Gregory B. Pauly ${ }^{\mathrm{a}}$, John J. Crayon ${ }^{\mathrm{c}}$, H. Bradley Shaffer ${ }^{\mathrm{a}}$ \\ ${ }^{a}$ Section of Evolution and Ecology, 2320 Storer Hall, University of California, Davis, CA 95616, USA \\ ${ }^{\mathrm{b}}$ Turtle Bay Museum and Arboretum, Redding, CA 96009, USA \\ ${ }^{\mathrm{c}}$ USGS, Western Ecological Research Center, Department of Biology, University of California, Riverside, CA 92521, USA
}

Received 6 April 2002; received in revised form 15 October 2002; accepted 9 November 2002

\begin{abstract}
The western pond turtle Emys (formerly Clemmys) marmorata is declining throughout its range, primarily due to loss of habitat via urbanization and conversion to agriculture. Urban waterways present several important challenges to freshwater turtle populations, but they also present an opportunity to maintain declining species in a ubiquitous habitat that has high public visibility. The arboretum waterway on the University of California, Davis campus is an example of an extensively altered urban habitat that supports a relatively large E. marmorata population. Over the last 6 years, we monitored the turtle population inhabiting the arboretum waterway to determine the demographic health of the population, and the challenges and opportunities that urban environments pose for pond turtles. Since 1993, the naturally existing arboretum pond turtle population has declined by approximately $40 \%$ and has shown little natural recruitment. During this time, we also introduced 31 headstarted turtles into the arboretum. Headstarting is the process of raising juveniles in captivity until they have outgrown their period of greatest vulnerability to predators, and then releasing them into the wild. Our headstarting results demonstrate that this contentious strategy is a viable option for adding young turtles to the population, although it does not address the causes of decline. Over the course of our study, we encountered nine species of non-native turtles in the waterway, and these appear to be a serious threat to the native species. As more habitat becomes urbanized, it is increasingly important to understand how freshwater turtles, such as E. marmorata, adapt to urban waterways and the impact of non-native turtles on native turtle species. Our strong feeling is that urban waterways can provide habitat for viable populations of freshwater turtles and showcase them to the public, but both the aquatic and terrestrial habitat must be managed according to the biological requirements of individual species.
\end{abstract}

(C) 2003 Elsevier Science Ltd. All rights reserved.

Keywords: Western pond turtle; Clemmys marmorata; Emys marmorata; Introduced species; Urban waterway; Red-eared slider; Trachemys scripta elegans; Competition; Headstart

\section{Introduction}

Throughout the world, turtles face an increasingly serious set of threats to their survival (reviewed in Klemens, 2000), making them one of the most severely threatened vertebrate clades. One turtle species that is declining throughout its range is the western pond turtle Emys (formerly Clemmys) marmorata Baird and Girard. Based on recent phylogenetic analyses, the genus "Clemmys" as traditionally used is not monophyletic, and therefore requires redefinition (Bickham et al. 1996;

\footnotetext{
* Corresponding author. Tel.: + 1-530-752-6754; fax: + 1-530-752-

E-mail address: pqspinks@ucdavis.edu (P.Q. Spinks).
} 1449 .
Lenk et al., 1999; Holman and Fritz, 2001; Feldman and Parham, 2001). We follow Bickham et al. (1996), Feldman and Parham (2001) and Parham and Feldman (2002) in using the existing genus Emys for the monophyletic group that contains the previously recognized species Emys orbicularis, Emydoidea blandingii, and Clemmys marmorata, rather than Holman and Fritz (2001) in their recommendation of placing marmorata in a monotypic genus Actinemys. Although once common from Washington south to Baja California, Mexico (Iverson, 1992; Germano and Bury, 2001), E. marmorata is now considered endangered in Washington, threatened in Oregon, and a species of special concern in California (Gray, 1995). A major cause of these declines is loss or modification of habitat, primarily 
from urbanization (Hays et al., 1999) and agriculture (Germano and Bury, 2001).

Within California, formally suitable habitat is continually modified to accommodate urban development and agriculture (Brattstrom, 1988; Jennings and Hayes, 1994) resulting in the extirpation of many E. marmorata populations. For example, in southern California, known localities for E. marmorata declined from 87 in 1960 to 20 in 1987 (Brattstrom, 1988). More recently, Holland (1991a) has found that only six to eight viable populations remain south of the Santa Clara River system in southern California. Southern California is a region of extreme urbanization, and many biologists attribute one or more aspects of urbanization, including water, shoreline, and vegetation management, to the decline of $E$. marmorata populations (Jennings and Hayes, 1994). It is important to recognize, however, that urbanization does not always result in turtle population declines (Moll, 1980; Moll and Moll, 2000). Increased nutrient input and water temperatures can lead to an increased prey base and may provide other physiological benefits as well (Knight and Gibbons, 1968; Lindeman, 1996; Souza and Abe, 2000). Thus, urban environments may be able to serve as effective refuges for turtle populations if they are properly managed.

Effective conservation of E. marmorata, or any freshwater turtle, requires assessing the impacts of urbanization and habitat modification on turtle populations. To this end, we have studied a population of E. marmorata in an urbanized environment for the past 6 years. The turtle population in the University of California, Davis (UCD) campus arboretum waterway exemplifies the plight of E. marmorata in an urban environment. The arboretum waterway has been completely modified from its original state, but it continues to support a relatively large turtle population. Although the density of E. marmorata in the waterway superficially suggests a healthy population, an examination of population demography indicates that the population is senescent and recruitment is far below levels needed to sustain it through time. Also, comparisons between current population estimates and an estimate generated in 1993 indicate that the arboretum population is declining.

The impact that urbanization has on turtle habitat depends on how the terrestrial and aquatic habitat is utilized or managed. Managing for freshwater turtle species can be difficult, as minor alterations to either aquatic or terrestrial habitat may have drastic impacts on a population's long-term survival. Urbanized aquatic habitats are likely to suffer increased channelization and siltation, a reduction in aquatic vegetation, and degradation of appropriate basking sites. Suitable terrestrial habitat for nesting, hibernating, and aestivating may be scarce or non-existent. Urbanization brings other challenges for freshwater turtles such as increased take due to encounters with humans, pets, and subsidized pre- dators (Mitchell, 1988; Garber and Burger, 1995; Mitchell and Klemens, 2000), and death from road traffic (Ashley and Robinson, 1996). If the aquatic or surrounding upland habitat is unsuitable for long-term population viability, the ensuing decline may remain unnoticed for many years due to the long life span and delayed sexual maturity of most turtle species (Congdon et al., 1993, 1994). For example, many emydid turtles have life expectancies in the wild from 20 to upwards of 40 years (Gibbons and Semlitsch, 1982; Congdon et al., 1993) and mean time to first reproduction for 18 freshwater turtle species averaged 11.9 years (Shine and Iverson, 1995). As a result, apparently healthy populations may actually be senescent (the "living dead" populations of Klemens, 2000).

In this paper, we discuss the survival of E. marmorata in the UCD arboretum waterway, using it as a model for the management challenges and opportunities presented by highly modified, heavily urbanized habitats. One of our most unexpected findings in the arboretum waterway is the number and variety of introduced turtles. Over the course of our study, we encountered nine species of non-native turtles. The red-eared slider, Trachemys scripta elegans, was the most commonly encountered turtle in the waterway, greatly outnumbering the native E. marmorata population. The impact that these non-native species have on the native turtles is difficult to assess, but we report some potential problems and document several observations that suggest $E$. marmorata may be negatively impacted by introduced turtles.

\section{Methods}

Extending for $2.4 \mathrm{~km}$ along the southern edge of the UCD campus, the arboretum waterway has a surface area of approximately ten acres, an average depth of about one meter, and an average width of nearly 15 meters (Fig. 1). The arboretum waterway is the original North Fork of Putah Creek, which flowed from the Inner Coast Range into the Sacramento River floodplain. In the 1930s, the original creek was rerouted to the south to prevent flooding of the town of Davis, and the remaining creek bed was later modified into a storm water collecting area and ornamental waterway within the newly developed campus arboretum (Connors and Darby, 1991). A strip of terrestrial habitat, generally 10-30 m wide and adjacent to the waterway, is intensively landscaped and heavily used for teaching and recreation (Fig. 1). This landscaped area also includes a $1.5-2.5 \mathrm{~m}$ wide paved walking path that nearly encircles the arboretum waterway resulting in frequent traffic from walkers, joggers, bicyclists and maintenance vehicles. Virtually all of the surrounding vegetation is nonnative, and most is heavily irrigated. 


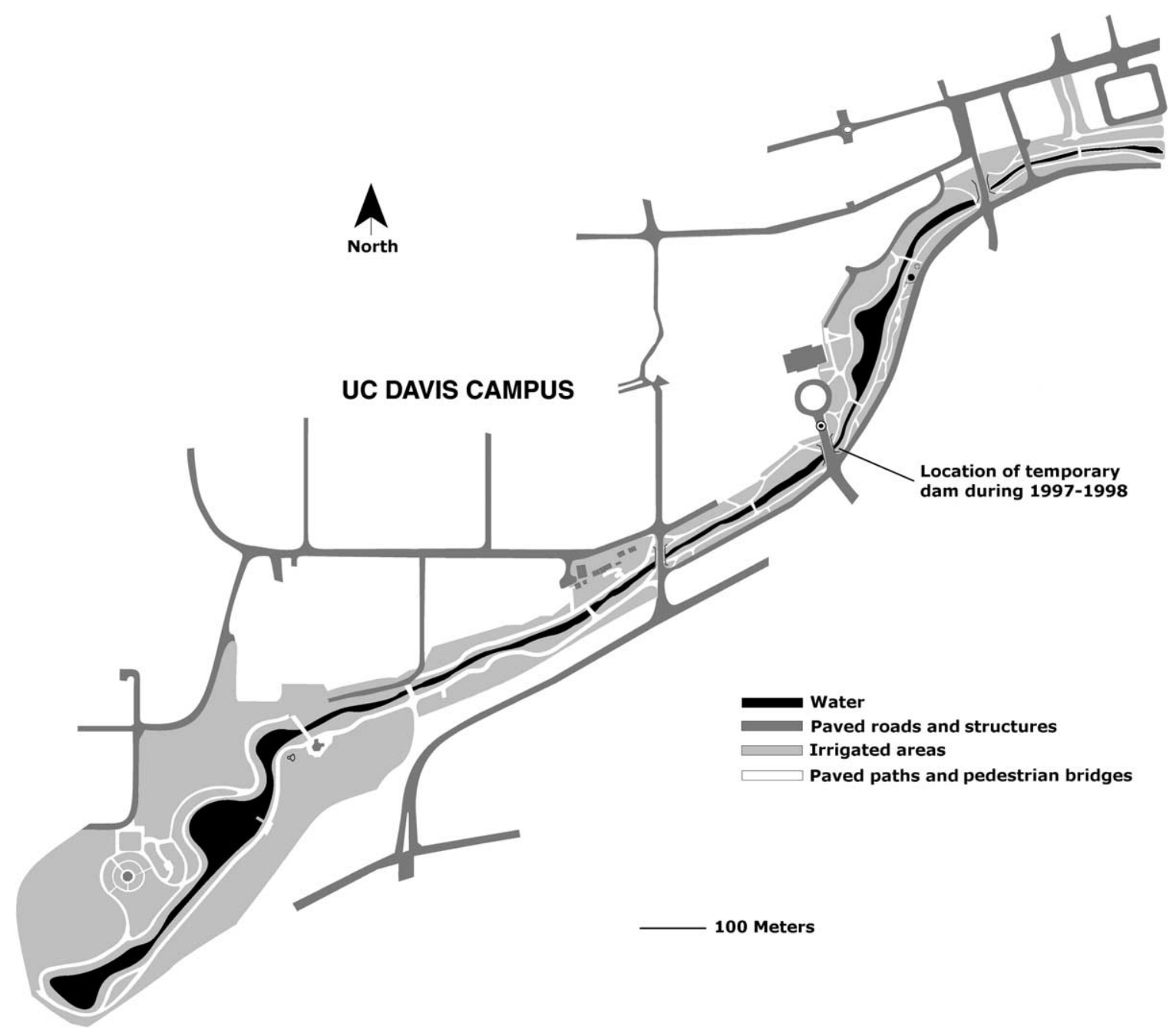

Fig. 1. Map of the waterway of the University of California, Davis campus arboretum, Yolo County California.

We began making casual observations on turtles in the arboretum in 1989, although our formal data collection started in 1996. From September 1996 to August of 1997 we captured turtles by hand, dip net, and basking traps (Macculloch and Gordon, 1978). From 1997 to 2000 , turtles were captured by hand, dip net and submersible traps. The submersible traps were set underwater and checked every three hours, with no resulting mortality. Beef liver, canned tuna/sardines and fresh salmon scraps were used as bait, and turtles were caught equally well with all baits.

Up to 1994 , non-native turtles were sporadically removed from the waterway. In 1996, we began an intensive program of capturing, recording the number and species identification, and removing non-native turtles from the waterway. We also began individually marking E. marmorata (by notching the marginal scutes) and, from this point on, began collecting markrecapture data for native turtles. Beginning in 1997, we also recorded weight and length measurements of most captured turtles in order to quantify population demo- graphics of turtles in this urbanized waterway. Individuals were measured along the midline of the carapace to the nearest $1 \mathrm{~mm}$ (straight-line length) and weighed to the nearest gram. All captured females were palpated for shelled eggs. Gravid females were sometimes hormonally induced to oviposit (Ewert and Legler, 1978), and the eggs were incubated in moist vermiculite as part of a separate experiment (Crayon, unpublished). Juvenile $E$. marmorata resulting from these eggs were raised in captivity (headstarted) and released into the waterway. Twenty-seven E. marmorata hatchlings were hatched in 1994 and released as 2-year old subadults in 1996. In 1998, another four were hatched from a single female, headstarted for 6 months, and released in the spring of 1999.

In 1997 and 1998, the waterway was drained and cleared of debris and accumulated silt, and we took advantage of this unique opportunity to thoroughly survey the turtle population. In July of 1997, a dam was installed that bisected the waterway (Fig. 1). The eastern half was pumped dry, allowing us to capture otherwise 
elusive species from the waterway. Unfortunately, several E. marmorata were drowned in pump inflow pipes during this project. In July of 1998, this process was repeated in reverse to drain and clean the west end of the waterway. To avoid further accidental mortality, we captured turtles and maintained adult E. marmorata in temporary holding ponds until September 1998 when the work was completed and they were returned to the waterway. No mortality occurred during this stage of the project. All $P$ values were calculated using the Monte Carlo $\mathrm{R} \times \mathrm{C}$ Contingency Table program v. 2.1 (Engels, 1988). Population estimates were calculated using the Schnabel Mark-Recapture estimate (Schnabel, 1938) and also by using the CAPTURE program (available from: http:// www.mbrpwrc.usgs.gov/software.html\#capture).

\section{Results}

\subsection{Emys marmorata population dynamics}

Although we started to work in the arboretum in 1994, our quantitative records for E. marmorata span the period from September 1996 to May 2001. Since September 1996, we captured 76 individual E. marmorata 170 times (headstarted turtles were counted as first captured at the time of release). Of the 76,45 were nonheadstarted E. marmorata. To estimate the population sex ratio, we recorded the sex of all non-headstarted animals, including those initially captured as juveniles that were sexed (based on shell and tail morphology) as recaptured adults. This yielded a final tally of 27 males, 14 females, two individuals for which sex could not be determined, and two for which gender was not recorded.

To determine the total fraction of the population consisting of (non-headstarted) juvenile recruits requires a cutoff point for when an individual is adult or juvenile. This cutoff point can generally be determined visually, but for some individuals it is difficult to determine whether it is a small female or an immature. Based on a large, species-wide analysis, Holland (1991a) determined that E. marmorata typically attain sexual maturity at about $110 \mathrm{~mm}$ carapace length, and we used this as our cutoff point. In a few cases, we lacked carapace length but had recorded weight at time of capture. Weight and carapace length are highly correlated in our sample $\left(r^{2}=0.92\right)$; based on a least-squares regression, the predicted weight of a $110 \mathrm{~mm}$ turtle is about $225 \mathrm{~g}$ (Fig. 2). Based on length $(>110 \mathrm{~mm})$ or weight $(>225 \mathrm{~g}$ ), we determined juvenile/adult status for 43 of our 45 non-headstarted turtles. In all, nine were juveniles at time of first capture,

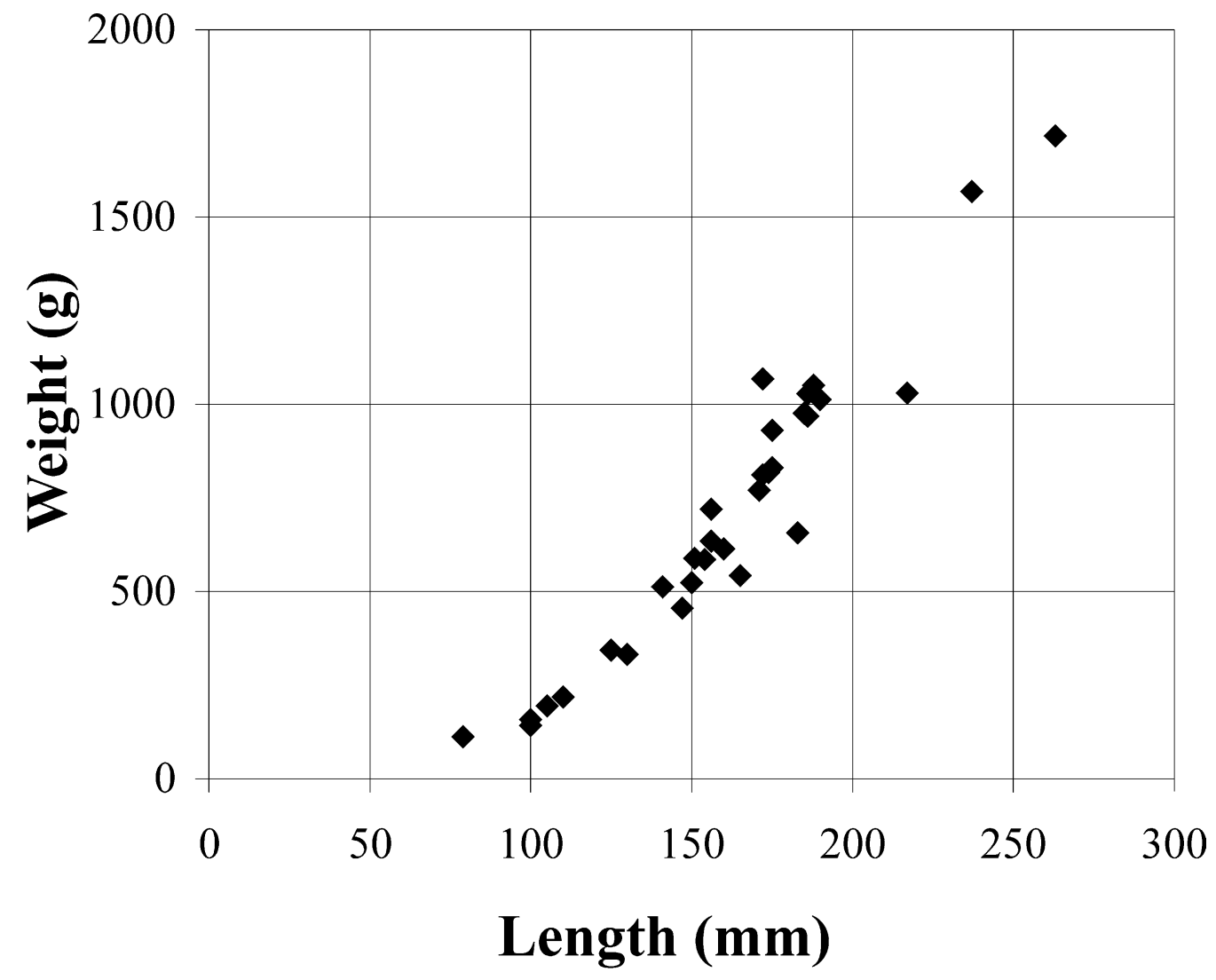

Fig. 2. Plot of carapace length vs. weight for Emys marmorata for first capture of all non-headstarted individuals in the arboretum waterway ( $n=32$, $\left.r^{2}=0.924\right)$. A linear regression (weight $=9.38 \times$ length -807.4$)$ predicts that sexual maturity $(110 \mathrm{~mm}$ carapace length; Holland, 1991a) is attained at approximately $225 \mathrm{~g}$. 
implying that there have been approximately 1.5 natural recruits/year to the arboretum population since 1996.

Previous to our work, the turtle population in the arboretum waterway was surveyed from 1991 through 1993 (Holland, 1994). Based on a Schnabel MarkRecapture estimate (Schnabel, 1938), Holland estimated the arboretum E. marmorata population to be 81 turtles (Holland, 1994). Our population estimates were derived in two ways, both based on non-headstarted turtles only. First, we calculated a Schnabel estimate for the arboretum population to compare with Holland's (1994) estimate. Next, we calculated a population estimate using the CAPTURE program (Table 1). Using the Schnabel Mark-Recapture method, we estimate the $E$. marmorata population to be 49 individuals. This implies a $40 \%$ reduction in the arboretum E. marmorata population in less than 10 years. For CAPTURE, the appropriate model for our data incorporates time specific changes in probability of capture. Under this model, we estimated the population to be 53 individuals $(95 \% \mathrm{CI}=48,66)$. We cannot statistically compare our estimate to the 1993 estimate since Holland (1994) did not provide confidence estimates of his mean. However, Holland's (1993) estimate is well outside of our $95 \% \mathrm{CI}$, suggesting that the arboretum population has declined over the last decade.

For the 33 headstarted turtles, 21 have been recaptured and four are known to be dead. Of the 21 , seven are females, 13 are male, and gender could not be determined for the remaining individual. One frequent criticism of headstarting is that individuals are inappropriately accustomed to humans, and can therefore be easily captured and removed from the population. Since October, 1996, we recaptured 44 of the 45 nonheadstarted turtles a total of 80 times, and 24 of the headstarted turtles were recaptured 57 times. Recapture rates were not significantly different for headstarted vs. non-headstarted turtles $(P=0.45)$.

\subsection{Non-native turtles}

Although it is the only native freshwater turtle in California, E. marmorata was not the most common turtle in the waterway. Since 1994, we have removed a minimum of 125 Trachemys scripta elegans from the waterway. From 1998 to the present we captured 19

Table 1

Population estimates for the arboretum waterway Emys. marmorata population

\begin{tabular}{lll}
\hline Year & Estimation method & Population estimate \\
\hline 1993 & Schnabel & 81 \\
2001 & Schnabel & 49 \\
2001 & CAPTURE & $53(95 \%$ CI $=48,66)$
\end{tabular}

Estimates were derived with the Schnabel method (1938) and by using the CAPTURE software. females ( $n=17$ were weighed at the time of capture, mean $=1166$ g, S.D. $\pm=21.6 \mathrm{~g}), 14$ males $(n=12$, mean $=$ $747 \mathrm{~g}$, S.D. $\pm=18.6 \mathrm{~g})$ and six juveniles $(n=2,39$ and $66 \mathrm{~g}$, respectively). Trachemys s. elegans is well known as a successful invasive species around the world (Iverson, 1992) and the arboretum population appears to be reproducing successfully. For example, in 1994, eight of the nine female T. s. elegans were gravid. These gravid females were induced to oviposit and the eggs of these individuals, as well as those collected from six gravid E. marmorata were artificially incubated. The E. marmorata and T. s. elegans eggs hatched equally well, with a hatch rate of $53 \%$ for E. marmorata and $70 \%$ for T. s. elegans (but hatch rates are not significantly different $P=0.37$ ) suggesting that both species are producing viable eggs in the arboretum habitat.

In addition to T. s. elegans, we captured and removed eight other species from the waterway (Table 2). Of these, four species are emydid turtles native to North

Table 2

Family, genus and species of turtles caught during the years 1994-2001 at the UC Davis arboretum waterway

\begin{tabular}{|c|c|c|c|}
\hline Year & Family & Species & $\begin{array}{l}\text { Number } \\
\text { captured }\end{array}$ \\
\hline \multirow[t]{5}{*}{1994} & Emydidae & Emys marmorata & $\mathrm{nr}$ \\
\hline & & Trachemys scripta elegans & 37 \\
\hline & & Graptemys pseudogeographica & 4 \\
\hline & & Pseudemys spp. & 1 \\
\hline & Chelydridae & Chelydra serpentina & 1 \\
\hline \multirow[t]{3}{*}{1995} & Emydidae & Emys marmorata & $\mathrm{nr}$ \\
\hline & & Pseudemys spp. & 1 \\
\hline & & Trachemys scripta elegans & 23 \\
\hline \multirow[t]{2}{*}{1996} & Emydidae & Emys marmorata & 49 \\
\hline & & Trachemys scripta elegans & 12 \\
\hline \multirow[t]{4}{*}{1997} & Emydidae & Chrysemys picta & 2 \\
\hline & & Emys marmorata & 11 \\
\hline & & Trachemys scripta elegans & 15 \\
\hline & Kinosternidae & Kinosternon subrubrum & 1 \\
\hline \multirow[t]{7}{*}{1998} & Emydidae & Chrysemys picta & 1 \\
\hline & & Emys marmorata & 36 \\
\hline & & Glyptemys muhlenbergii & 1 \\
\hline & & Pseudemys concinna & 1 \\
\hline & & Trachemys scripta elegans & 23 \\
\hline & Geoemydidae & Chinemys reevesii & 1 \\
\hline & Trionychidae & Apalone spinifera & 1 \\
\hline \multirow[t]{2}{*}{1999} & Emydidae & Emys marmorata & 33 \\
\hline & & Trachemys scripta elegans & 7 \\
\hline \multirow[t]{4}{*}{2000} & Emydidae & Chrysemys picta & 1 \\
\hline & & Emys marmorata & 34 \\
\hline & & Trachemys scripta elegans & 4 \\
\hline & Trionychidae & Apalone spinifera pallida & 1 \\
\hline 2001 & Emydidae & Emys marmorata & 7 \\
\hline
\end{tabular}

Numbers in the right-hand column indicate number captured/year $(\mathrm{nr}=$ not recorded). For Emys marmorata, this includes all captures, including headstarted animals. 
America. Graptemys pseudogeographica, native to southern Canada and much of the eastern United States (Iverson, 1992), was only encountered in 1994. Three of the four G. pseudogeographica captured were gravid females and the remaining individual was a male. Although our sample size is small, among the three clutches of G. pseudogeographica, only five of 31 eggs hatched, suggesting that only limited reproduction may be occurring for this non-native species. We captured three Pseudemys spp.; one individual was captured in 1994, one in 1995 and the last in 1998. The males captured in 1994 and 1995 were only identified to genus, but the 1998 female was $P$. concinna, a wide-ranging species found from southern Illinois south to Florida and northern Mexico (Iverson, 1992). Chrysemys picta was captured in two different years, a juvenile in 1998 and a female in 2000. Chrysemys picta is native to North America from southern Canada to northern Mexico, although it is absent from most of the southwestern US including California (D. Starkey, personal communication). Other known California introductions of $C$. picta include Siskiyou County in northern California and the Cayuma River in southern California (Stebbins, 1985).

The final emydid turtle species that we captured in the waterway was Glyptemys (Clemmys) muhlenbergii (see Holman and Fritz, 2001; Parham and Feldman, 2002), an endangered species that inhabits swamps and bogs in the eastern United States (Conant and Collins, 1991). Based on notches in the marginal scutes and a unique imperfection in the eighth right marginal, this turtle was identified as male L10/R2, a former resident of Zoo Atlanta (Atlanta, Georgia). This individual, as well as three additional G. muhlenbergii and two Clemmys guttata were stolen from the zoo in 1995. L10/R2 and his mate were originally purchased from an animal dealer in 1967 at which time they were estimated to be 15 years old. The turtle died from a fungal infection shortly after his capture; it is not known if the infection was present prior to his recapture, nor how long he had survived in the waterway. At the time of his death, this turtle was approximately 47 years old and represents the oldest known G. muhlenbergii maintained in captivity (Snider and Bowler, 1992).

In addition to Emydidae, we captured and removed representatives of four other turtle families from the waterway. The Kinosternon subrubrum (Kinosternidae), captured in 1997 is a species normally found from Connecticut west to Indiana and south to Texas and Florida (Iverson, 1992). We also captured two Apalone spinifera, a trionychid turtle inhabiting slow-moving waterways from southern Ontario and Quebec west to Montana and south to northern Florida and northern Mexico (Iverson, 1992). The Chelydra serpentina, family Chelydridae, captured in 1994 is native to Southern Canada and North America east of the Rocky Mountains.
Previous introductions of $C$. serpentina have been documented in California, where its importation is now illegal (Stebbins, 1985; Iverson, 1992). The Chinemys reevesii represents the only Old World species we have encountered. Chinemys reevesii is a wide-ranging geoemydid turtle native to China, Korea, Taiwan and Japan (Iverson, 1992).

\section{Discussion}

\subsection{Population ecology}

Turtles are characterized as long-lived organisms with delayed sexual maturity and a long reproductive life span. These traits, together with high adult survivorship and low egg and hatchling survivorship, result in a stable population age structure that should be dominated by juveniles and subadults (Congdon et al., 1993, 1994). As a result, the ratio of nonreproductives to reproductives should greatly exceed one, and adults should represent only a small fraction of the population (Gibbs and Amato, 2000). For example, Congdon et al. (1994) found that this ratio was approximately $18: 1$ for the common snapping turtle, Chelydra serpentina.

Within the arboretum waterway, we find that the opposite situation exists. Adults dominate the E. marmorata population, with only one hatchling and eight other juveniles encountered since 1996. Due to their small size, feeding habits, and tendencies to remain near shoreline vegetation, it is possible that our sampling program failed to effectively account for hatchling turtles. However, we observed and caught $T$. s. elegans hatchlings and a relatively large number of juveniles, suggesting that we are encountering small turtles when they are present. In addition, if recruitment is occurring for $E$. marmorata, then we should expect to capture or observe juveniles and young adults since they are certainly susceptible to observation and capture.

Several studies (Congdon et al., 1993, 1994; Heppell et al., 1996; Gibbs and Amato, 2000) suggest that population stability of turtles is primarily influenced by adult and juvenile survivorship, while nest and neonate survival play a less critical role. However, for populations suffering from severely limited recruitment, both factors are likely to be significant contributors to population decline. Successful recruitment is dependent on both the survival of gravid females as well as nest and neonate survival. Our data point to both factors as contributing to the unstable demographic structure that we found in the arboretum waterway.

Nest and/or neonate survival for E. marmorata appear to be nearly zero in the urbanized arboretum setting. Locating a suitable nesting site may be an extremely difficult challenge in this habitat. In a study of 275 E. marmorata nests, Holland and Bury (in press) 
found that under natural conditions, nests averaged 45 $\mathrm{m}$ from the water and ranged from 1.5 to $402 \mathrm{~m}$ away from the shoreline. Female E. marmorata seem to prefer sites situated on well drained clay/silt soils, with a slope of less than 15 degrees, that are dominated by grasses and herbaceous vegetation, but lack shrubs and trees. Within many urbanized waterways, and certainly in the arboretum waterway, this type of habitat is almost nonexistent. Most terrestrial habitat near the water has a slope approximating 45 degrees and is dominated by shrubs and trees. More distant regions are flat, but they are mainly open lawn and irrigated gardens. The inability to find suitable nesting habitat within the arboretum may be a major factor in explaining the almost complete absence of non-headstarted juveniles in the population.

When females do nest, the eggs may be exposed to unsuitable incubation conditions characteristic of urbanized habitat. The arboretum waterway and most urbanized habitat is extremely fragmented, and turtles are forced to lay their eggs near ecological edges where poor nesting success due to increased predation pressure is far more likely (Temple, 1987). Critically, E. marmorata produce hard-shelled eggs that are incapable of expanding in response to increasing internal pressure due to moist incubation substrates. Under conditions of excess moisture, the eggshell ruptures and the embryo rarely survives (Feldman, 1982; Crayon, unpublished data). Under artificial incubation conditions, eggs from T. s. elegans and G. pseudogeographica hatched under substrate moisture levels that caused E. marmorata eggs to crack (Crayon, unpublished data). Most of the grounds bordering the arboretum waterway are irrigated during the spring and summer months when turtle eggs develop. In California's Mediterranean climate, these are normally rain-free months, and E. marmorata eggs have evolved under this rainfall regime. The relatively high substrate moisture conditions common around the waterway may reduce $E$. marmorata hatching success but not reduce hatching success of introduced species.

One strategy for increasing total population size is to introduce headstarted turtles. Over the course of this study we introduced 31 headstarted turtles to the waterway. Although four are known to have died and another three have never been recaptured, the 24 turtles that still exist in the waterway have drastically shifted the age structure of the population. Of the 1996 cohort, at least six are now morphologically identifiable as adult females and these females are probably reproductively active. One of us (Crayon) dissected two of the dead headstarted female turtles in 1997 and found developing follicles on their ovaries. Thus, headstarting appears to be a viable strategy for increasing recruitment in urbanized settings.

However, it is important to recognize that there are several potential drawbacks to headstarting. Headstarting has been described as a halfway technology because, although it may generate an observable increase in abundance, it does not address the actual causes of decline (Frazer, 1992; Moll and Moll, 2000). As a result, the ultimate goal of a self-sustaining population may never be achieved (Haskell et al., 1996). Furthermore, several authors have questioned whether captivity alters feeding behaviors and preferences, courtship, and nesting compared to wild individuals (Frazer, 1992; Siegel and Dodd, 2000). Within the arboretum waterway, we captured headstarted turtles with the same frequency as native turtles, implying that they are as wary as their wild counterparts. Although not a solution we favor for long-term population sustainability, headstarting is a viable, short-term solution for maintenance and growth of populations in urbanized pond turtle habitats. Whether or not headstarting can bring a population up to a minimum self-sustaining size is an open question both for E. marmorata and other freshwater turtles (Haskell et al., 1996).

\subsection{Altered habitat}

For species that require both terrestrial and aquatic habitat, alteration of either can seriously affect a population's viability. This realization has led many states to enact legislation requiring a $30.5 \mathrm{~m}$ upland buffer zone to surround aquatic habitats (Burke and Gibbons, 1995). In some cases, altered habitats including wastewater treatment plants, fortuitously provide adequate conditions for healthy populations (Germano and Bury, 2001), and long-term studies of these modified habitats may provide important management insights for more urban populations. However, the conversion of the North Fork of Putah Creek into the arboretum waterway resulted in the total alteration of the native habitat and a non-sustaining Emys population. The creek was channelized and impounded and, at the waterline, the banks were covered in either concrete or wire-wrapped rock for erosion control, and, areas bordering the waterway are now irrigated. In both direct and indirect ways, these changes affect many aspects of E. marmorata habitat, from basking and nesting sites to water temperature.

A major problem E. marmorata encounters in urban waterways is access to adequate basking sites. Emys marmorata often bask on emergent logs or branches (Holland, 1994; Hays et al., 1999). In a landscaped situation or a flood control area, emergent logs and branches (deadwood) are often removed. Consequently, turtles are forced to bask at sub-optimal sites on shore, or at a few prime sites where both intra and interspecific competitive interactions are likely (Bury and Wolfheim, 1973; Lindeman, 1999). For example, on a recent visual survey of the arboretum waterway (24 March, 2002), of 23 basking turtles, 13 were clustered in a single $5 \mathrm{~m}$ stretch of secluded shoreline adjacent to a dead snag, 
five more were in a very secluded $2 \mathrm{~m}$ area, and the remaining five were scattered across the rest of the waterway. Lindeman (1998) found a strong positive correlation between the presence of deadwood basking areas and map turtle (Graptemys) abundance in the southeastern United States, a result similar to that found by Holland and Bury (in press) for E. marmorata. Moreover, Koper and Brooks (2000) found that juvenile growth of Chrysemys picta is positively correlated with basking frequency but not food availability, suggesting that a lack of sufficient basking opportunities may have severe negative consequences for juveniles.

Recent studies by Burke and Gibbons (1995) and Germano and Bury (2001) highlight the importance of suitable nesting and overwintering habitat for freshwater turtles. In the case of E. marmorata, individuals may overwinter in terrestrial or aquatic habitat. In a study of 12 E. marmorata along the Trinity River of northern California, Reese and Welsh (1998) found that turtles overwintered up to $500 \mathrm{~m}$ from shore, and Slavens (1995) suggests that E. marmorata may change hibernation sites several times during a single winter. Along many urbanized waterways, including the arboretum, it is unlikely that adequate upland habitat exists for these terrestrial activities. Considering that turtles may be nesting and overwintering hundreds of meters from the shore, it is unlikely that even a mandated 30.5 $\mathrm{m}$ upland buffer zone would provide enough area to allow for normal terrestrial activity.

\subsection{Predation and accidental mortality}

Urbanization can also lead to increased numbers of turtle and nest predators. Skunks, raccoons, otters, coyotes, rats, and other species are natural predators of E. marmorata nests (Holland, 1994; Hayes et al., 1999). In studies of turtle populations not impacted by urbanization, natural predators are often a major source of mortality (Mitchell, 1988). In urbanized settings, predator loads on the various life stages of turtles generally differ from those in more natural settings. In the arboretum waterway, rats and to a lesser extent wading birds are found at very high densities and these almost certainly impact egg and juvenile survival (Mitchell and Klemens, 2000). However larger mesopredators (coyotes, otters) are absent, potentially reducing predation pressure on adult turtles. Additionally, urbanization is often accompanied by the introduction of non-native species. Bullfrogs (Rana catesbiana) and largemouth bass (Micropterus salmoides) are both introduced species known to prey upon hatchling E. marmorata (Moyle, 1973 and Holland, 1991b, respectively), and bullfrogs exist at low densities in the arboretum.

An indirect, but potentially important source of mortality in urbanized areas results from the high frequency of encounters with people and their pets. Garber and
Burger (1995) documented the decline of two wood turtle [Glyptemys insculpta (see Holman and Fritz, 2001; Parham and Feldman, 2002)] populations in the eastern US that was synchronous with the initiation of human recreation to the area. Interestingly, both the $G$. insculpta populations and the arboretum E. marmorata population demonstrated skewed sex ratios consistent with the loss of adult females during their respective declines. In almost all areas of the arboretum, females must traverse a paved walkway to nest, incurring a higher risk of encounters with humans relative to sympatric males. We have seen at least one mortality due to interactions with a pet dog, and even infrequent death of mature females will negatively impact turtle populations (Congdon et al., 1993; Garber and Burger, 1995). Other events, including waterway maintenance activities such as those occurring in 1997-1998, also lead to increases in adult mortality.

\section{Non-native turtles}

With the exception of $G$. muhlenbergii, the non-native turtles recovered from the waterway are common in the pet and food trade. Although some introductions may result from the intentional release of "rescued" individuals intended for human consumption, our feeling is that most non-native turtles present derive from the pet trade. Our reasoning is simply that turtles purchased for food must, by law, be slaughtered before sale (although this law is relatively recent in California), whereas those in the pet trade are explicitly purchased by individuals whose goal is to keep turtles alive and healthy. The majority of these species can become quite aggressive and quickly outgrow most aquariums or outlast the owner's commitment to care for them. As a result, some pet owners unwilling to care for their turtles release them into nearby bodies of water. This scenario is implicated for introductions elsewhere (Luiselli et al., 1997; Chen and Lue, 1998), and is particularly likely for T. s. elegans, which is the most common turtle to the pet (and food) trade and the waterway. Within the waterway, most captured individuals were large adults, which are likely to be the most difficult to care for, while intermediate sized individuals were less common. This population structure is similar to that documented at other sites where T. s. elegans is introduced (Luiselli et al., 1997; Chen and Lue, 1998). The juvenile T. s. elegans we have encountered were all hatchlings and yearlings. These are most likely offspring of adults released into the waterway since juveniles under $10 \mathrm{~cm}$ in length are not legally available within the pet trade in the United States.

The impact of introduced turtles on native turtle populations is difficult to assess, but their impact is almost certainly negative. Our observations suggest competition may exist between $T$. s. elegans and $E$. 
marmorata for basking sites. Because much of the water/shore interface is either concrete or wire-wrapped rock, we usually observe turtles of all species basking at a few prime sites. At these sites, we frequently observe interspecific confrontations. In some instances, as $E$. marmorata approach occupied basking sites, they will gape at basking T. s. elegans (a behavior also directed at conspecifics; Bury and Wolfheim, 1973). Lindeman (1999) has shown that in confrontations for basking sites between $T$. s. elegans and other emydid turtles, the largest turtle successfully displaces the smaller, regardless of species. Female T. s. elegans can grow to more than twice the size of E. marmorata (Stebbins, 1985), and of the turtles we measured in the waterway $T$. $s$. elegans weigh, on average, $38 \%$ more than E. marmorata. If the outcome of competitive interactions at basking sites is determined by size, then it is likely that $T$. $s$. elegans will out-compete E. marmorata for basking sites. Further observations are needed to determine the extent to which E. marmorata may be negatively affected.

Introduced turtles also have the potential to introduce disease. Populations of E. marmorata in Washington were decimated by a respiratory infection in 1990 and Hays et al. (1999) implicate introduced T. s. elegans as a likely vector for the infection. While the majority of the E. marmorata we captured in the arboretum waterway appeared healthy, there is some disease-related mortality in the waterway as evidenced by four disease-related fatalities discovered in 1997 and one in 2002 (additionally, a female T. s. elegans found in 2000 showed signs of a disease-related mortality, as did the G. muhlenbergii). With non-native turtles being released into the arboretum waterway annually, there is a high probability that some diseases will be introduced as well.

Finally, even in the absence of additional introductions, introduced T. s. elegans appear to have a more balanced sex ratio than native $E$. marmorata. Since we have kept records, we found a male:female ratio for non-headstarted E. marmorata of 27:14, compared to $13: 19$ for the introduced $T$. s. elegans. This adult sex ratio is significantly different $(P=0.037)$. Because both species have temperature-dependent sex determination, the difference may be due to a combination of incubation and mortality factors. In either case, the difference in sex ratio suggests that the Trachemys population has a higher potential reproductive rate than E. marmorata.

\section{Conclusion and recommendations}

The arboretum waterway on the UCD campus exemplifies the opportunities and the hazards that freshwater turtles encounter in urbanized waterways. On the one hand, the extremely artificial habitat presented by the arboretum currently supports a large turtle population, including an estimated 75 E. marmorata (including headstarted turtles) and an additional 15 T. s. elegans that were observed after trapping ended in 2001. However, the extremely low level of observed recruitment, relatively frequent adult mortality and lower population estimate of non-headstarted turtles compared to 1993 all point to the native population being non-sustaining, at least in the absence of headstarting or similar measures.

The key elements of maintaining healthy populations of E. marmorata in urban waterways appear to be straightforward and achievable, and fall into three broad categories. First, the habitat should be maintained with the requirements of the turtles in mind. Basking and nesting habitat are the two key elements that are frequently missing, and they must be included in a managed urban ecosystem. Second, headstarting is a viable management strategy, although it does nothing to ameliorate the causes of low recruitment and mortality. However, as a labor-intensive method to enhance recruitment, headstarting works. Finally, control of introduced turtles is probably a necessary step in protecting E. marmorata, and our efforts have shown that an aggressive trapping program can control populations of non-native turtles. Recent legislation in California outlawing the sale of live turtles for food is a positive step in reducing well-meaning people from releasing animals, and public education and awareness programs (including signage at urban waterway sites) may deter pet owners from releasing unwanted animals.

We have several specific recommendations for habitat enhancement in urban waterways that are managed for freshwater turtles. First, basking logs are almost never provided, yet they are an integral part of the life history of many species. Logs that are anchored in place can be visually attractive and provide focal points for viewing turtles and other wildlife by the public. Second, appropriate nesting habitat that is protected from humans and their commensal species (dogs, racoons, skunks) must be identified and managed. For Emys, this means providing patches of non-irrigated land adjacent to waterways. Since it is not known how widely females search for appropriate nesting sites, or whether they discriminate between high and low quality sites, we recommend that several sites be situated at different points adjacent to a waterway. Low, non-obtrusive fencing could encourage nesting only in appropriate areas and exclude egg and turtle predators. Finally, we need to understand the actual competitive interaction between introduced T. s. elegans and native turtles, both in California and elsewhere. Over 30 million T. s. elegans were exported to 58 countries during 1994-1997 alone (Salzberg, 1998), contributing to the establishment of this species in temperate and tropical countries around the world. Its impact on native turtle populations has not been addressed, and remains an important problem in freshwater turtle conservation, particularly in urban settings where $T$. s. elegans introductions are most common. 


\section{Acknowledgements}

We thank Tag Engstrom, Josh Nelson, Dave Phillips, and Dave Starkey for field assistance. Dennis Herman and Jeff Lovich identified the G. muhlenbergii and Diane Cary at the UC Davis arboretum provided Fig. 1. We also thank John Iverson and A. Ross Kiester for providing comments on an earlier version of this manuscript.

\section{References}

Ashley, E.P., Robinson, J.T., 1996. Road mortality of amphibians, reptiles and other wildlife on the Long Point Causeway, Lake Erie, Ontario. Canadian Field Naturalist 110, 403-412.

Bickham, J.W., Lamb, T., Minx, P., Patton, J.C., 1996. Molecular systematics of the genus Clemmys and the intergeneric relationships of emydid turtles. Herpetologica 52, 89-97.

Brattstrom, B.H., 1988. Habitat destruction in California with special reference to Clemmys marmorata: A perspective. In: Delisle, H.F., Brown, P.R., Kaufman, B., McGurty, B.M. (Eds.), Proceedings of the Conference on California Herpetology. Southwest Herpetological Society, Van Nuys, pp. 13-24.

Burke, V.J., Gibbons, J.W., 1995. Terrestrial buffer zones and wetland conservation: a case study of freshwater turtles in a Carolina Bay. Conservation Biology 9, 1365-1369.

Bury, R.B., Wolfheim, J.H., 1973. Aggression in free-living pond turtles. Bioscience 23, 659-662.

CAPTURE. (Available from: http://www.mbrpwrc.usgs.gov/software. html\#capture).

Chen, T.H., Lue, K.Y., 1998. Ecological notes on feral populations of Trachemys scripta elegans in Northern Taiwan. Chelonian Conservation and Biology 3, 87-90.

Congdon, J.D., Dunham, A.E., Van Loben Sels, R.C., 1993. Delayed sexual maturity and demographics of Blanding's turtle (Emydoidea blandingii): implications for conservation and management of longlived organisms. Conservation Biology 7, 826-833.

Congdon, J.D., Dunham, A.E., Van Loben Sels, R.C., 1994. Demographics of common snapping turtles (Chelydra serpentina): implications for conservation and management of long-lived organisms. American Zoologist 34, 397-408.

Connant, R., Collins, J.T., 1991. A Field Guide to Reptiles and Amphibians Eastern and Central North America. Houghton, New York.

Connors, D.H., Darby, J.L., 1991. Lake Spafford: An Investigation of Water Quality Improvement Options. Department of Civil Engineering University of California, Davis, Davis, California.

Engels, W., 1988. Monte Carlo $\mathrm{R} \times \mathrm{C}$ Contingency Table Program v. 2.1. Available from http://www.wisc.edu/genetics/CATG/pstat.

Ewert, M.A., Legler, J.M., 1978. Hormonal induction of oviposition in turtles. Herpetologica 34, 314-418.

Feldman, M., 1982. Notes on reproduction in Clemmys marmorata. Herpetological Review 13, 10-11.

Feldman, C.R., Parham, J.F., 2001. Molecular phylogenetics of emydine turtles: taxonomic revision and the evolution of shell kinesis. Molecular Phylogenetics and Evolution 22, 388-398.

Frazer, N.B., 1992. Sea turtle conservation and halfway technology. Conservation Biology 6, 179-184.

Garber, S.D., Burger, J., 1995. A 20-yr study documenting the relationship between turtle decline and human recreation. Ecological Applications 5, 1151-1162.

Germano, D.J., Bury, R.B., 2001. Western pond turtles (Clemmys marmorata) in the Central Valley of California: status and population structure. Transactions of the Western Section of the Wildlife Society $37,22-36$.
Gibbons, J.W., Semlitsch, R.D., 1982. Survivorship and longevity of a long-lived vertebrate species: how long do turtles live? Journal of Animal Ecology 51, 523-527.

Gibbs, J.P., Amato, G.D., 2000. Genetics and demography in turtle conservation. In: Klemens, M.W. (Ed.), Turtle Conservation. Smithsonian Institution Press, Washington, pp. 207-217.

Gray, E.M., 1995. DNA fingerprinting reveals a lack of genetic variation in northern populations of the western pond turtle (Clemmys marmorata). Conservation Biology 9, 1244-1254.

Haskell, A., Graham, T.E., Griffin, C.R., Hestbeck, J., 1996. Size related survival of headstarted redbelly turtles (Pseudemys rubriventris) in Massachusetts. Journal of Herpetology 30, 524-527.

Hays, D.W., McAllister, K.R., Richardson, S.A., Stinson, D.W., 1999. Washington State Recovery Plan for the Western Pond Turtle. Washington Department of Fish and Wildlife, Olympia.

Heppell, S.S., Crowder, L.B., Crouse, D.T., 1996. Models to evaluate headstarting as a management tool for long-lived turtles. Ecological Applications 6, 556-565.

Holland, D.C., 1991a. A Synopsis of the Ecology and Status of the Western Pond Turtle Clemmys marmorata in 1991. Report to National Ecological Research Center. United States Fish and Wildlife Service, San Simeon, CA.

Holland, D.C. 1991b. A Synopsis of the Ecology and Current Status of the Western Pond Turtle (Clemmys marmorata) in 1991 (Unpublished Report). United States Fish and Wildlife Service, National Ecological Research Center, Fort Collins, Colorado.

Holland, D.C., 1994. The Western pond turtle: habitat and history. United States Department of Energy, Bonneville Power Administration Environment, Fish and Wildlife, Portland, Oregon.

Holland, D.C., Bury, B. Clemmys marmorata (Baird and Girard 1852) western pond turtle. In: Pritchard, P.C.H., Rhodin, A.G.J., (Eds.), The Conservation Biology of Freshwater Turtles. Lunenburg, MA: Chelonian Research Foundation (in press).

Holman, A.J., Fritz, U., 2001. A new emydine species from the middle Miocene (Barstovian) of Nebraska, USA with a new generic arrangement for the species of Clemmys sensu McDowell (1964) (Reptilia: Testudines: Emydidae). Zoologische Abhandlungen Staatliches Museum für Tierkunde Dresden 51, 331-353.

Iverson, J.B., 1992. A revised checklist with distribution maps of the turtles of the world. Privately printed, Richmond, Indiana.

Jennings, M.R., Hayes, M.P., 1994. Amphibian and Reptile Species of Special Concern in California. Final Report, Submitted to the California Department of Fish and Game, Inland Fisheries Division, Rancho Cordova.

Klemens, M.W. (Ed.), 2000. Turtle Conservation. Smithsonian Institution Press, Washington.

Knight, A.W., Gibbons, J.W., 1968. Food of a painted turtle, Chrysemys picta in a polluted river. American Midland Naturalist 80, 558-562.

Koper, N., Brooks, R.J., 2000. Environmental constraints on growth of painted turtles (Chrysemys picta) in northern climates. Herpetologica 56, 421-432.

Lenk, P., Fritz, U., Joger, U., Winks, M., 1999. Mitochondrial phylogeography of the European pond turtle, Emys orbicularis (Linnaeus 1758). Molecular Ecology 8, 1911-1922.

Lindeman, P.V., 1996. Comparative life history of painted turtle (Chrysemys picta) in two habitats in the inland Pacific Northwest. Copeia 1996, 114-130.

Lindeman, P.V., 1998. Of deadwood and map turtles (Graptemys): an analysis of species status for five species in three river drainages using replicated spotting-scope counts of basking turtles. Chelonian Conservation and Biology 3, 137-141.

Lindeman, P.V., 1999. Aggressive interactions during basking among four species of emydid turtles. Journal of Herpetology 33, 214-219.

Luiselli, L., Capula, M., Capizzi, D., Filippi, E., Jesus, V.T., Anibaldi, C., 1997. Problems for conservation of pond turtles (Emys orbicularis) in Central Italy: is the introduced red-eared turtle (Trachemys scripta) a serious threat? Chelonian Conservation and Biology 2, 417-419. 
Macculloch, R.D., Gordon, D.M., 1978. A simple trap for basking turtles. Herpetological Review 9, 133.

Mitchell, J.C., 1988. Population ecology and life histories of the freshwater turtles Chrysemys picta and Sternotherus odoratus in an urban lake. Herpetological Monographs 2, 40-61.

Mitchell, J.C., Klemens, M.W., 2000. Primary and secondary effects of habitat alteration. In: Klemens, M.W. (Ed.), Turtle Conservation. Smithsonian Institution Press, Washington, pp. 5-32.

Moll, D., 1980. Dirty river turtles. Natural History 5, 42-49.

Moll, E.O., Moll, D., 2000. Conservation of river turtles. In: Klemens, M.W. (Ed.), Turtle Conservation. Smithsonian Institution Press, Washington, pp. 126-155.

Moyle, P.B., 1973. Effects of introduced bullfrogs, Rana catesbeiana, on the native frogs of the San Joaquin Valley, California. Copeia 1973, 1. 18-22.

Parham, J.F., Feldman, C., 2002. Generic revisions of emydine turtles. Turtle and Tortoise Newsletter 6:3, 28-30.

Reese, D.A., Welsh, H.H., 1998. Habitat use by western pond turtles in the Trinity River, California. Journal of Wildlife Management 62, 842-853.

Salzberg, A., 1998. Chelonian conservation news. Chelonian Conservation and Biology 3, 147-150.
Schnabel, Z.E., 1938. The estimation of the total fish population of a lake. American Mathematical Monthly 45, 348-352.

Shine, R., Iverson, J.B., 1995. Patterns of survival, growth and maturation in turtles. Oikos 72, 343-348.

Siegel, R.A., Dodd, C.K., 2000. Manipulation of turtle populations for conservation: halfway technologies or viable options? In: Klemens, M.W. (Ed.), Turtle Conservation. Smithsonian Institution Press, Washington, pp. 218-238.

Slavens, K., 1995. The Status of the Western Pond Turtle in Klickitat County, including notes on the 1995 Survey of Lake Washington, King County. Unpublished Report on file at Washington Department of Fish and Wildlife.

Snider, A.T., Bowler, J.K., 1992. Longevity of reptiles and amphibians in North American collections. Herpetological Circular No. 21.

Souza, F.L., Abe, A.S., 2000. Feeding ecology, density and biomass of the freshwater turtle, Phrynops geoffroanus, inhabiting a polluted urban river in south-eastern Brazil. Journal of the Zoological Society of London 252, 437-446.

Stebbins, R.C., 1985. A Field Guide to Western Reptiles and Amphibians. Houghton, New York.

Temple, S.A., 1987. Predation on turtle nests increases near ecological edges. Copeia 1987, 3. 250-252. 